\title{
Russia in Africa: A Search for Continuity in a Post-Cold War Era
}

\author{
MAXIM MATUSEVICH*
}

\begin{abstract}
This commentary proposes to connect Russia's present activities in Africa to the history of Soviet involvement on the continent during the Cold War. While post-Soviet Russia pursues very difficult foreign policy objectives in its relations with African states, in doing so it often draws on the relationships, partnerships, and formal and informal networks forged during the Cold War. An enduring continuity can be observed in Russia's ongoing efforts to present itself as an alternative to the West. In the past, the Soviet model of development tended to emphasize socialist modernization. Under Vladimir Putin, Russia has abandoned its promotion of socialism to pursue crude economic interests via its business elite, based on values that appear to be in stark contrast to the conventions of Western liberalism.
\end{abstract}

\section{Introduction $^{1}$}

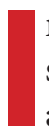
n the summer of 2018, three Russian journalists were ambushed and murdered in the Central African Republic (CAR). The three had traveled to the CAR in pursuit of a story on the Wagner Group, a Russian paramilitary firm, with links to the Kremlin and alleged to be involved in an ongoing civil conflict ravaging the central African nation. Over the last few years, the firm's personnel showed up in a number of conflict zones -from eastern Ukraine to Syria. Following his recent election, President Faustin-Archange Touadera of the CAR has forged close links with the Kremlin; he presently has a Russian security advisor and Russians have been reported serving in his presidential guard. ${ }^{2}$ The Wagner Group enjoys a patronage by President Vladimir Putin's close associate, the businessman Yevgeny Prigozhin. The same Prigozhin became known in the United States soon after he was sanctioned by the U.S. Department of the Treasury for his involvement in the Ukraine conflict, and especially after he had been linked to a "troll factory" company in St. Petersburg, Russia (the Internet Research Agency, Ltd.) and subsequently indicted in the United States for his role in funding and organizing the disruption to the 2016 presidential election. ${ }^{3}$ The murdered journalists were known to have
* Seton Hall University, U.S. 2019, pp. 25-39 


\section{Soviet attitudes towards} independent Africa fluctuated

to reflect both the changes

in the general "party line,"

but also the vagaries of

superpower competition been affiliated with opposition media organizations in Russia and personally with Mikhail Khodorkovsky, a prominent exiled Putin critic and his one-time prisoner. ${ }^{4}$ There is little indication that the truth about the murky triple murder in the CAR will come out any time soon, but the tragedy served an instant reminder of Russia's evolving role in Africa as well as an illustration of some surprising and enduring continuities between the Soviet and post-Soviet involvements on the continent.

The Russia of Vladimir Putin has been growing more confident on the international stage, seeking to reclaim or rebrand its faded superpower credentials. After years of neglect and quiet in Russian-African relations, the resurging Kremlin is once again pursuing an increasingly assertive African policy, which has seen an increase in contacts and deals, especially in the areas of military support and arms trade, as well as mineral extraction. ${ }^{5}$ It is also significant that quite a few members of the new, post-Soviet Russian elite have backgrounds in foreign intelligence and the KGB. Probably most prominent among them is Igor Sechin, the CEO of the oil company Rosneft and a close friend and associate of Vladimir $\mathrm{Pu}$ tin, who spent part of the 1980s serving under cover at Soviet missions in Angola and Mozambique. ${ }^{6}$ To better understand Russia's role in Africa and its attempts to reinvent itself as a serious power broker and a geopolitical contender on a par with the United States and China, one needs to examine the complexity of Russia's historical ties to the continent, with an eye on accounting for the continuities that can be traced back to the not-sodistant Soviet past.

\section{The Soviet Union in Africa: A Different Kind of Power}

The Soviets first arrived in Africa at the height of the Cold War and on the heels of African decolonization. Their goals on the continent presented an uneasy mixture of idealistic aspirations and sober Cold War pragmatism. Throughout the decades of its existence, the Soviet Union never failed to emphasize the contrast between its own ideological commitments to anti-racism and decolonization and the history of Western racism and colonialism. ${ }^{7}$ Soviet leadership could and did claim a degree of continuity between the history of Russia in Africa (marked by the absence of Russian colonialism on the continent) and the Soviet critique of colonialism and North American racism. Some Soviet observers even alluded to the ambivalence of such categories as "white" and "European" when applied to Russia. ${ }^{8}$ There are 
no reasons to doubt the sincerity of the Soviet desire to uphold African independence and thus realize the demands of Soviet anti-colonial rhetoric. At the same time, the Soviet interest in Africa was necessarily tied to the overriding concerns of Cold War geopolitical rivalries. Soviet attitudes towards independent Africa fluctuated to reflect both the changes in the general "party line," but also the vagaries of superpower competition. While the Cold War scholarship on Soviet involvement in Africa, including sub-Saharan Africa, often stressed its ideological thrust, a number of post-Cold War studies emphasized the importance the Soviets attached to the more pragmatic considerations of geopolitical and economic realism, sometimes well hidden under the shroud of the obligatory Marxist-Leninist rhetoric. ${ }^{9}$

On the eve of African independence and at the time of the expanding movement for equal rights in the United States, the Soviet Union sorely lacked the expertise on Africa and, beyond the customary anti-racist slogans, the country's general population remained largely ignorant of the history and nuance of race relations in the West. While Soviet writers and propagandists sought to expose the depravity of Western racism, Soviet scholarship on Africa remained parochial and burdened by ideological interpretive models (e.g., Stalin's insistence on the necessity of proletarian revolutions in the colonies) that were reflective of the prevailing party line in Moscow but hardly of local African conditions. ${ }^{10}$ Under Stalin, any sys- tematic study of Africa in the Soviet Union proved to be an uncertain and even risky occupation. In fact, several prominent Africanists perished in the purges, and those who survived thought it wise to channel their intellectual curiosity elsewhere. ${ }^{11}$ In the course of the Second World War, the Soviet Union began to abandon its early internationalist ideals, resorting to conservative statism and as a result, the Soviet society grew progressively isolationist and even xenophobic. To be sure, the anti-racist and anti-colonial propaganda continued unabated, but its tone and volume were being adjusted in accordance with Soviet foreign policy objectives.

The arrival of independence in sub-Saharan Africa coincided with the liberalization of the Soviet Union under its new leader Nikita Khrushchev. After the oppressive Stalinist decades, the Soviet Union entered a period of Khrushchevian "thaw, during which the country became relatively more open to the outside world. While Stalin had remained wary of socialist transformations in the colonial world Khrushchev was brimming with hope and enthusiasm. Khrushchev heralded "the awakening of the peoples of Africa" from the same podium of the $20^{\text {th }}$ Party Congress (1956) where he famously denounced Stalin's crimes. A year later, on 6 March 1957, Ghana became the first sub-Saharan African nation to gain its independence from Britain. The Soviet press devoted extensive and highly celebratory coverage to African decolonization and the government dispatched Ivan Potekhin, the doyen of African 


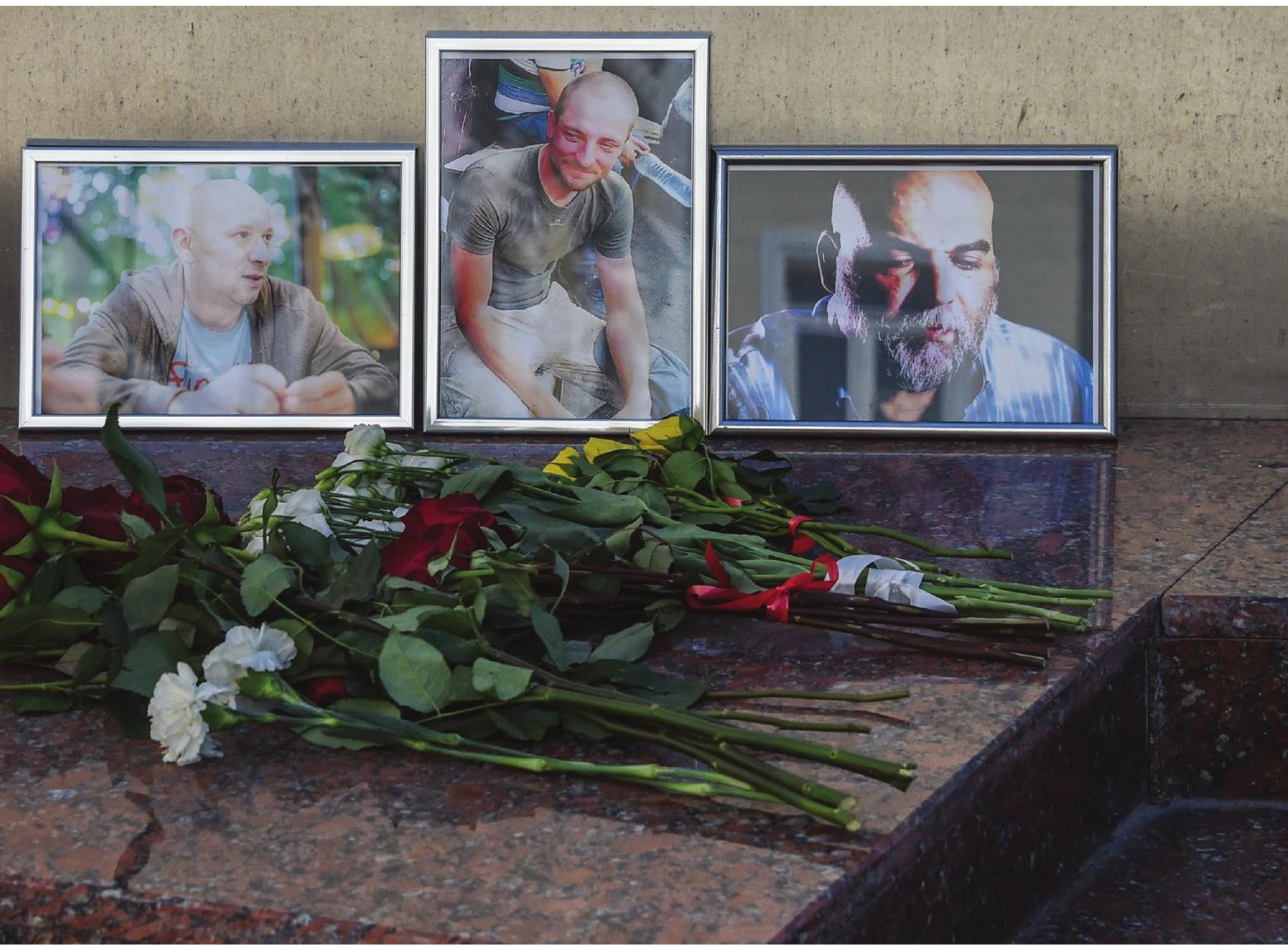

Flowers left

in front of the photographs

of Russian

journalists (L-R)

Rastorguyev,

Radchenko, and

Dzhemal, who

were killed in the

Central African

Republic on July

$30,2018$.

VASILY MAXIMOV/ AFP / Getty Images studies in the Soviet Union, to attend the First African Peoples' Conference in Accra (1958). ${ }^{12}$

After the decades of Stalinist isolationism, and in the wake of the 1957 Youth Festival in Moscow, the Soviets now looked for friends in the developing world where the emerging post-colonial nations seemed perfect candidates for just such a friendship. This was the point emphasized by the great pan-Africanist W.E.B. Du Bois in 1958 when he argued for the creation within the Soviet Academy of Sciences of "an institute for the study of Pan-African history, sociology, ethnography, anthropology and all cognate studies." 13 Within months, the Central Committee of the CPSU adopted, in July 1959, a special resolution provisioning the creation of a research institute of African studies (later to become known as the Africa Institute). ${ }^{14}$ Following this, another party resolution of February 5, 1960 announced the founding of a new university to train "the national cadres for the countries of Asia, Africa, and Latin America." Friendship University, also known as Lumumba University, would emerge as the flag- 
ship institution of higher learning, catering to the needs of third world students (as well as to the needs of the Cold War Soviet foreign policy). ${ }^{15}$

In advance and as a result of these initiatives the number of Africans in the USSR increased almost ten-fold, from 72 to over 500, between 1959 and 1961, eventually reaching some 5,000 by the end of the decade. ${ }^{16}$ However, few of these students harbored deep Marxist convictions, rather they saw in the Soviet Union less of a "promised land" of racial equality and more of an educational opportunity of choice. Even those who arrived with the backing of foreign Communist parties or their front organizations often showed a lack of the expected ideological credentials or at least a failure to apply them in the USSR. African students of the 1960s, 1970s, and 1980s rarely entered the Soviet mainstream. Despite being officially hailed as the "natural allies" of the regime they, in fact, often acted as the conduits of political dissent and the propagators of the alternative cultural forms (jazz and rock-n-roll music, Western fashions, etc.). Young Africans in the Soviet Union felt free to question and even challenge the ironclad rules of Soviet political and public discourse: forming their own independent ethnic and national associations they complained to the authorities and refused to accept administrative regulations which they found invasive or superfluous. In other words, they enjoyed and exercised a far greater degree of political and cultural autonomy than their Soviet peers. ${ }^{17}$

\section{Ironically, by the early 1970s,} the bulk of Soviet trade with sub-Saharan Africa was directed towards the nations that could be hardly described as either socialist or "progressive"

However, this elated stage in Soviet relations with sub-Saharan Africa did not last long. Khrushchev's fall from power in 1964 was followed by a succession of African coup d'etats that saw the ousting of some of Moscow's closest African friends. The regimes of Nkrumah in Ghana, Keita in Mali and Ben Bella in Algeria -all succumbed to a series of military conspiracies, which reflected the growing popular disillusionment with the inefficiency and corruption of their "founding fathers." In Kenya, the Soviet-sympathizer Odinga increasingly came into conflict with Jomo Kenyatta's regime, eventually ending up relegated to the periphery of Kenyan politics. An earlier attempt by the Soviets to insert themselves in the Congo conflict had only worsened the position of the embattled nationalist Prime Minister Patrice Lumumba, and likely hastened his eventual demise. The new military regime showed little interest in any socialist experiments and the Soviets had effectively lost ground. For the next decade or so, until mid-1970s, Soviet efforts in sub-Saharan Africa proceeded with a far more pragmatic set of priorities. 
Soviet success in establishing

a place for themselves in the former Portuguese colonies and the fact that so many African nations accepted Moscow's growing prominence in the south of the continent was in no small amount due to the firmness of the Soviet position on the white minority regimes in Southern Africa did not particularly endear themselves to the Soviet Africa experts with their version of "scientific socialism." Ironically, by the early 1970 s, the bulk of Soviet trade with sub-Saharan Africa was directed towards the nations that could be hardly described as either socialist or "progressive" -Ivory Coast, post-Nkrumah Ghana, Nigeria, Kenya, etc. Certainly, the Soviets persisted in trying to sell their model of modernization to Africans, especially through the implementation of extravagant development projects, such as the ill-fated Ajaokuta steel mill in Nigeria. On the positive side, the Soviets often voiced support for the Organization of African Unity (OAU) and aligned with Africans to vote on the issues of mutual concern (e.g., liberation of Southern Africa, anti-Apartheid resolutions, and condemnations of Western imperialism and neo-colonialism) at the United Nations and other international bodies, becoming, as Zaki Laïdi put it, sub-Saharan Africa's de facto "ally in protest." ${ }^{\prime 9}$ But in its overall approach to independent African nations, the Soviet Union was more concerned with their geopolitical value, the potential for economic cooperation, and their willingness to side with Moscow, even if occasionally, in its ongoing Cold War contest with the West.

Another twist in the history of Soviet involvement in Africa came soon after 1974 with two important new developments on the continent. A wave of decolonization throughout Lusophone Africa in the aftermath of the 1974 Portuguese Revolution and an overthrow, that same year, 
of the regime of Haile Selassie in Ethiopia both dramatically altered the power balance in Southern Africa and in the Horn. Several traditionally pro-Western regimes were removed from the scene and new radical forces, keen on cultivating new partnerships with the socialist camp and not above exploiting the Soviet-American rivalry in Africa to advance their own political objectives came into power. The Soviets responded by intensifying their involvement in sub-Saharan Africa and also by expressing a more positive vision for African development -that of "socialist orientation." After the fiascos of the 1960s, few experts in Moscow were prepared to describe the post-colonial activities in African nations as "socialism." The new formula provided the long overdue ideological flexibility: the select friendly states, especially those identifying with the aspirations of Marxism-Leninism, were assumed to be pursuing the path towards socialism. The journey was expected to be long and arduous but the hope of eventual arrival could be drawn upon to justify Soviet "fraternal" support.

What followed was the waning of détente between the superpowers and the subsequent transformation of southern and northeastern Africa into the central fronts of the socalled "second Cold War." In Angola, the Soviets became entrenched in a drawn-out civil war that involved at least three different liberation movements -the MPLA, the FNLA, and UNITA. Angola achieved independence in 1975 but even before this could be fully realized the conflict became internationalized -with the Soviets backing the fellow MPLA Marxists; the Chinese (at this point the bitter rivals of the USSR for the dominance in the international communist movement) throwing their weight behind UNITA and FNLA; and the Americans and Zairians oscillating in their support between the two anti-MPLA parties. The situation worsened when in late October 1975 Angola was invaded by the forces of the apartheid South Africa, the nation notorious for the racism practiced inside its borders but equipped with impeccable anti-communist credentials and thus committed to stopping the MPLA. South African invasion was followed by a dramatic increase in Soviet material support for the MPLA and an involvement of yet another actor -the Soviet Union's close ally Cuba. By April 1976, Cuba had 36,000 troops stationed and fighting in Angola. Cuban involvement proved to be critical in halting the South African advance. ${ }^{20}$ From that point, until the arrival of Gorbachev's reforms in the mid-1980s, the Soviet Union would continue to enjoy a working relationship with MPLA-ruled Angola as well as with another Lusophone Marxist regime in Mozambique. It was during this period that such present-day Russian oligarchs as Igor Sechin established their KGB bona fides on assignments in Africa.

Soviet success in establishing a place for themselves in the former Portuguese colonies and the fact that so many African nations accepted Moscow's growing prominence in the 
south of the continent was in no small amount due to the firmness of the Soviet position on the white minority regimes in Southern Africa. The Soviets at that time never wavered in their condemnation of the apartheid rule in South Africa and Southern Rhodesia. In fact, the Soviets provided more than just moral and diplomatic support: they actively supplied and trained anti-apartheid militants of the African National Congress (ANC) of South Africa and the South-West Africa People's Organization (SWAPO) of Namibia and the Zimbabwe African People's Union (ZAPU) fighters who were waging guerilla warfare against the white minority regime in Rhodesia. In this respect, the Soviets enjoyed a clear moral advantage over the Americans and Europeans, who at the height of the Cold War often chose to side with such unsavory "allies" as the racist regime in South Africa. Whatever other reservations they harbored about Soviet involvement in Africa or in regards to the applicability of Soviet modernization solutions to African conditions a large number of African states welcomed Soviet assistance to the various liberation movements in Southern Africa -one of several areas where Soviet efforts in Africa met with qualified success. ${ }^{21}$

Soviet involvement in the Horn of Africa, however, renders itself to a more complex analysis and interpretation. After the pro-Western emperor of Ethiopia Haile Selassie had been deposed by the military committee (also known as the Dergue) and in the ensuing fight for power, Moscow was initially wrong footed. Despite his pro-American sympathies, the relationship between Haile Selassie and the Soviets also had its positive aspects; the diplomatic ties between the two countries dated back to Second World War, during which, incidentally, Ethiopia and the USSR faced the same mortal enemy -the Axis powers. Prior to the 1974 Ethiopian coup, the Soviets had cultivated close links with Ethiopia's hostile neighbor Somalia, ruled by the self-proclaimed socialist Siade Barre. Moscow clearly entertained plans to establish advance naval bases and possibly bases for strategic bombers at Berbera on the Indian Ocean coast. By the mid1970s the USSR had embarked upon several construction projects in Somalia, including dredging the harbor and modernizing and expanding Berbera port facilities. It appears that the Somalis recoiled at what they saw as the Soviets pursuing their own strategic objectives in its geopolitical rivalry with Washington in the Indian Ocean. Somalia was more concerned with wrestling the province of Ogaden from Ethiopian control. Once it became clear that his Soviet allies would not support an offensive in the Ogaden, Said Barre ditched the alliance, expelled the Soviet advisers from the country, and, in July 1977, proceeded with the invasion. In a classical Cold War case of shifting alliances, the Soviets abandoned by their former Somali friends embraced instead the Dergue-controlled Ethiopia - a change of heart and partnership that was made easier by the Ethiopian military leader's (Mengistu Haile Miriam) timely conversion to Marxism-Leninism. As in Angola, the 
Cubans followed in Moscow's steps and sent troops to the Horn to assist Ethiopians; their involvement was certainly crucial in turning the tide of the war in Addis Ababa's favor. ${ }^{22}$

As Soviet involvement in Africa's conflict zones grew the Soviet Union's African policies came under the scrutiny of and eventually reconsidered by the new Soviet leadership. Assuming power in 1985, Mikhail Gorbachev launched an ambitious program of reforms, better known to the outside world as perestroika (restructuring) and glasnost (openness). Gorbachev was an unintentional revolutionary and in the beginning his reforms could be seen simply as a cautious attempt to jump-start the Soviet Union's decrepit planned economy and to remodel the increasingly inefficient system of party control. Inadvertently, however, the last Soviet general secretary opened up the floodgates of social and political change that included a wide-spread and vocal public criticism of Soviet foreign policy. Throughout perestroika, especially toward the end of the 1980s, the Soviet press, capitalizing on its newly found freedom, grew more and more critical of the Soviet presence in Africa. Soviet economic decline and the rapidly deteriorating living conditions for Soviet citizens were now routinely attributed to "too much help to the Third World." ${ }^{23}$ The Soviet Union under Gorbachev sought new rapprochement with the West, which necessarily entailed a re-evaluation of Soviet policies towards third world nations. It has been observed frequently that the calming of Cold War tensions

\section{As Russia's rivalry with the} West heated up and the rumblings of a "new Cold War" made some contemporary observers nervous, the continent of Africa once again re-emerged as a stage of and participant in the rivalries between the globe's major powers, particularly the United States, China, and

\section{Russia}

and its accompanying reassessment of Soviet foreign policy priorities also meant an irreversible regression from many areas of prior involvement, particularly in sub-Saharan Africa. Gorbachev's "new thinking" clearly prioritized "national reconciliation" over the pursuit of lofty ideological goals on the continent. Subsequently, during Perestroika the Soviet Union improved its relations not only with the United States but also with the continuing apartheid regime in South Africa. Gorbachev down-played the importance of liberation struggles in the south of Africa, understated their "revolutionary" content, and generally far preferred a negotiated compromise settlement. Africans residing at the time in the Soviet Union began to notice a sea change in the way the Soviet media reported on South Africa. The country, for decades described in the Soviet press as 


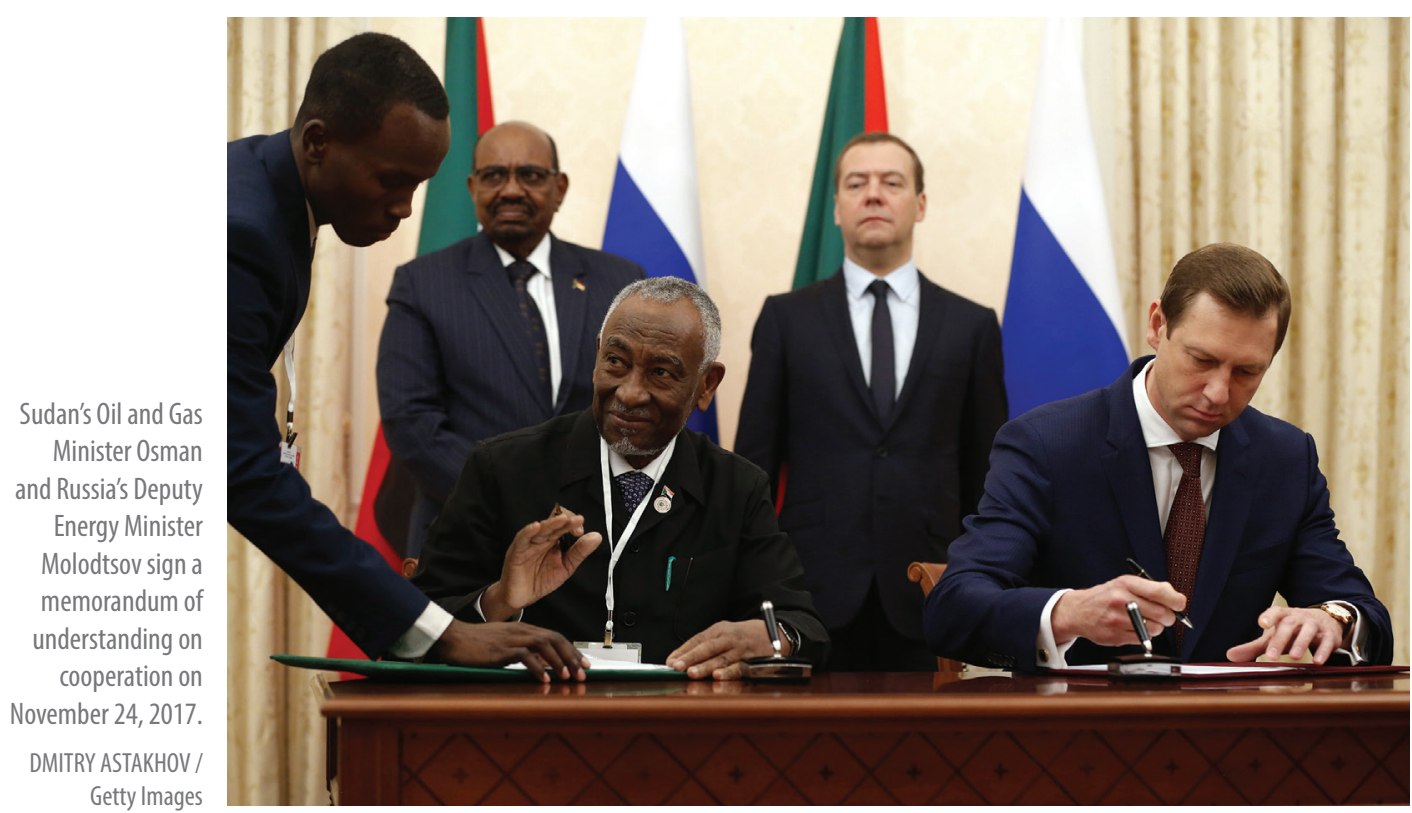

something akin to racist hell on earth was now treated much more sympathetically -praised for its economic successes and willingness to reach an understanding with its external and internal opponents, especially the ANC. Predictably, as the official and popular attitudes toward South Africa improved those toward other Africans soured. The Soviet Union, that for three decades had been extending generous educational scholarships to African students, now proceeded to severely restrict the number of such awards. Unfortunately for those students already present in the country everyday life was becoming progressively difficult as their sources of income began to dry up while they had to face and navigate their way within the society that was turning increasingly xenophobic and racist. ${ }^{24}$ As the Cold War drew to its end the Soviet Union's engagement on the African continent substantially withered away having fallen victim to the same experiment at social and political reformation that would culminate in the collapse of the Union of Soviet Socialist Republics.

\section{Russian-African Relations in the Post-Soviet Period}

The end of the Soviet Union also signified the end of most Soviet commitments on the continent. While Russia struggled to reconstruct and reassert itself in the aftermath of Soviet collapse, its presence and influence in Africa appeared marginal at best. This author remembers vividly the lobby of the vaunted Africa Institute in Moscow during the economically hard 1990s -much of the groundfloor space taken up by the kiosks selling books and souvenirs, while 
members of the institute staff busied themselves seeking employment opportunities abroad. Stripped of its Soviet glory, the institution became a symbolic representation of the former superpower's withdrawal from Africa. Until Russia's more recent resurgence, Africa remained on the periphery of Russian foreign policy. The number of African students residing in Russia was greatly reduced and those who stayed behind or arrived to pursue their education often had to face a climate of xenophobic hostility and open racism that would come to define the post-Soviet period. ${ }^{25}$

Russia's rekindled interest in Africa paralleled the oil boom of the first decade of the $21^{\text {st }}$ century, which fueled Russian expansionism. The 2008 war between Russia and Georgia became a watershed event that announced the arrival of a power set on reasserting its global influence. Before the decade had expired, a number of Western commentators started to sound the alarm about Russia's alleged plans to resurrect its one-time prominence in Africa. When in 2009, Russia's then president, Dmitry Medvedev, embarked on a multi-nation tour of Africa, some Western analysts grew worried, interpreting the Russian leader's visits to Egypt, Nigeria, Namibia, and Angola as an opening salvo of a major diplomatic offensive, aimed to score both economic and symbolic points. Writing in the Wall Street Journal, Ariel Cohen unfavorably compared President Barak Obama's outreach to engage African leaders in a conversation about climate change with the Russians' muscular and businesslike
After almost two decades of neglect, Africa is once again viewed in Moscow as an important counterbalance to what is perceived by the Kremlin as the West's deepseated antagonism towards Russia and its current leadership

approach. ${ }^{26}$ That tour indicated the parameters of the coming engagement, which would be primarily focused on securing massive arms contracts (Egypt and Sudan), cooperating in gas and oil extraction industries (Nigeria and Angola), and expanding Russia's presence in telecommunications (Angola) and even space exploration (Angola and Nigeria).

As Russia's rivalry with the West heated up and the rumblings of a "new Cold War" made some contemporary observers nervous, ${ }^{27}$ the continent of Africa once again reemerged as a stage of and participant in the rivalries between the globe's major powers, particularly the United States, China, and Russia. In this new contest, Russia, while circumscribed by its own economic deficiencies and the limited ability to project power globally, nevertheless possesses some important advantages. According to Paul Sikorsky, the post-Yeltsin Kremlin leadership recognized the importance of Russia's "historic footprint" 
For the present Russian leadership, Soviet involvement in Africa was less of a liability than a badge of honor an evidence of the Soviet Union's co-equal status as a

\section{superpower}

fund a new radio station, to finance a youth soccer tournament, and to launch television talk shows. Tellingly, the prize to the winner of a drawing and poetry contest, organized by the Russian embassy in CAR, was a beach holiday in Russia-annexed Crimea. ${ }^{32}$ At the moment and against a background of Washington's declined international visibility during the new isolationism of the Trump era, Moscow can boast of renewed ties with the traditionally friendly Ethiopia and with the autocratic regimes in Sudan and Egypt. Its relations with South Africa and oil-rich Angola have similarly experienced something of a renaissance. These gains are fueled by a number of factors, prominent among them Moscow's post-ideological and contractual approach to the conduct of foreign policy. For example, the Kremlin exhibits no obvious scruples in signing lucrative arms contracts with such authoritarian actors as President Abdel Fattah el-Sisi of Egypt or President Omar al-Bashir of Sudan. The fact that al-Bashir is wanted by the International Criminal Court for allegedly committing genocide doesn't appear to be an obstacle to massive sales of Russian military hardware to Sudan. Sisi's crackdown on democracy and civil society in Egypt yielded no protests from the Kremlin. On the contrary, Vladimir Putin warmly congratulated the Egyptian strongman on his recent controversial election victory, while Egypt and Russia are partnering up to build nuclear energy facilities in Egypt and develop a new industrial zone to accommodate an assortment of Russian companies. Egypt and Russia recently 
signed a major arms deal -in excess of $\$ 3.5$ billion- which provisions for the largest post-Soviet order of military aircraft. There is also some evidence of Russia's growing presence in eastern Libya, where Moscow had thrown its weight behind General Khalifa Haftar, a strongman with close ties to Egypt's Sisi. ${ }^{33}$

One should also consider a broader diplomatic and geopolitical context for the considerable warming of Russia's ties with an increasing number of African nations. After almost two decades of neglect, Africa is once again viewed in Moscow as an important counterbalance to what is perceived by the Kremlin as the West's deepseated antagonism towards Russia and its current leadership. In the aftermath of Putin's offensive against Russia's nascent civil society during the street protests of 2011-2012, and especially following Moscow's invasion of eastern Ukraine and the annexation of the Crimean peninsula in 2014, Western nations began to distance themselves from the Kremlin and eventually imposed a series of crippling economic sanctions. The election of Donald Trump to the presidency of the United States further complicated matters for Russia, for despite Trump's Putin-friendly rhetoric his administration has become embroiled in a roiling scandal related to Moscow's purported interference with the 2016 presidential election. Subject to additional sanctions and ostracized in the international arena, Russia finds itself in need of new friends and reliable allies, particularly at the UN General Assembly. One can hardly accuse Rus- sian leadership of being committed to an ideology, unless, of course, that ideology envisions an accumulation of lucrative arms sales and mineral extraction contracts by an elite group of businessmen close to President Vladimir Putin. Yet, the traditional opposition to and suspicion of the West seem to also play a role in this latest rapprochement with Africa.

\section{Conclusion}

In 2005, President Vladimir Putin famously referred to the collapse of the Soviet Union as "a major geopolitical disaster of the century." ${ }^{34}$ Putin and Russian power elites closely aligned with him often exhibit a peculiarly nostalgic attachment to the Soviet past, which they publicly evoke as a time of greatness. For the present Russian leadership, as well as for some of the former "Africa hands" who still consult the president, Soviet involvement in Africa was less of a liability than a badge of honor -an evidence of the Soviet Union's co-equal status as a superpower. Free of Soviet ideological constraints and illusions, the new Russia can be expected to deepen its engagement on the continent, to which it is still connected by a web of old Soviet networks. After all, a significant number of prominent African politicians, businessmen, and cultural figures received their education and lived for considerable periods of time in the Soviet Union. Russia's ambitions, in this case, have nothing to do with the promotion of a particular ideology, but rather they are symptomatic of an opportunistic and 
utilitarian approach to foreign policy. Post-Soviet Russia, just like China, embraces a doctrine of unsentimental self-interest and open disdain for neoliberal pieties that still have some currency among Western democracies. There must be a reason why the bulk of Russia's more recent contacts with African nations focused almost exclusively on the arms trade, military training, and resource extraction. African leaders seeking closer ties with Russia need not worry about being lectured on human rights and properly conducted elections. They know that the rhetoric of Soviet nostalgia notwithstanding, the new Russian elites harbor no particular attachment to abstract moral principles. They may welcome the opportunity to give the United States and China some run for their money and thus burnish Russia's international status but their main goal appears to be fairly uncomplicated: they are in Africa in search of major profits and new alliances and, in doing so, they are willing to build on the experience and memory of the Soviet Union's one-time prominence on the continent.

\section{Endnotes}

1. This commentary is an updated and extended version of the article published by the author earlier. Maxim Matusevich, "Revisiting the Soviet Involvement in Sub-Saharan Africa," History Compass, Vol. 9 (2009), pp. 1-10.

2. Cassandra Vinograd, "There's a New Battle for Influence in Central Africa and Russia Appears to Be Winning," The Washington Post (May 31, 2018), retrieved from https://www.washingtonpost.com/news/worldviews/wp/2018/05/31/ theres-a-new-battle-for-influence-in-central-africa-and-russia-appears-to-be-winning/?noredirect=on\&utm_term $=.736 \mathrm{e} 6 \mathrm{de} 3 \mathrm{e} 65 \mathrm{~d}$.
3. "Internet Research Agency Indictment," Case 1:18-cr-00032-DLF Document 1 Filed 02/16/18, retrieved October 19, 2018, from https://www. justice.gov/file/1035477/download.

4. Andrew Roth, "Russian Journalists Killed in CAR 'Were Researching Military Firm,"' The Guardian, (August 1, 2018), retrieved from https:// www.theguardian.com/world/2018/aug/01/russian-journalists-killed-central-african-republic-investigating-military-firm-kremlin-links.

5. See, Peter Beaumont, "Russia's Scramble for Influence in Africa Catches Western Officials Off-Guard," The Guardian, (September 11, 2018), retrieved from https://www.theguardian.com/ global-development/2018/sep/11/russias-scramble-for-influence-in-africa-catches-western-officials-off-guard.

6. See, "Igor Sechin, Head of Rosneft, Is Powerful as Never Before," The Economist, (December 15, 2016), retrieved October 20, 2018, from https:// www.economist.com/europe/2016/12/15/igorsechin-head-of-rosneft-is-powerful-as-never-before.

7. Meredith L. Roman, Opposing Jim Crow: African Americans and the Soviet Indictment of U.S. Racism, 1928-1937, (Lincoln, Nebraska: University of Nebraska Press, 2012).

8. See, Claude McKay, "Soviet Russia and the Negro, Part 1," Crisis, (December 1923), pp. 61-65; Claude McKay, "Soviet Russia and the Negro, Part 2," Crisis, (January 1924), pp. 114-118.

9. See, for example, Maxim Matusevich, No Easy Row for a Russian Hoe: Ideology and Pragmatism in Nigerian-Soviet Relations, 1960-1991, (Trenton: Africa World Press, 2003).

10. Woodford McClellan, "Africans and Black Americans in the Comintern Schools, 1925-1934," The International Journal of African Historical Studies, Vol. 26, No. 2 (1993), pp. 371-390.

11. Apollon Davidson and Irina Filatova, "African History: A View from Behind the Kremlin Wall," in Maxim Matusevich (ed.), Africa in Russia, Russia in Africa: Three Centuries of Encounters, (Trenton: Africa World Press, 2006), pp. 111-131.

12. See, Apollon B. Davidson (ed.), The Formative Years of African Studies in Russia, (Moscow: RAN, 2003).

13. William E. B. Du Bois, The Autobiography of W. E. B. DuBois: A Soliloquy on Viewing My Life from the Last Decade of Its First Century, $1^{\text {st }}$ Edition, (New York: International Publishers, 1968), pp. 1819. 
14. Sergey V. Mazov, "Sozdanie Instituta Afriki [The Creation of Africa Institute]," Vostok, No. 1 (1998), pp. 80-88.

15. Sergey V. Mazov, "Afrikanskie Studenty v Moskve v God Afriki [African Students in Moscow in the Year of Africa]," Vostok, No. 3 (June 1999), pp. 91-93.

16. These figures come from O. M. Gorbatov and L. la. Cherkasski, Sotrudnichestvo SSSR so stranami Arabskogo Vostoka i Afriki [Cooperation between the USSR and the Countries of Arab East and Africa], (Moscow: Nauka, 1973).

17. Maxim Matusevich, "Expanding the Boundaries of the Black Atlantic: African Students as Soviet Moderns," Ab Imperio, Vol. 2, (2012), pp. 325-350.

18. See, Edward E. Kolodziej and Roger E. Kanet, The Limits of Soviet Power in the Developing World, (Baltimore: The Johns Hopkins University Press, 1989).

19. Zaki Laïdi, The Superpowers and Africa: The Constraints of a Rivalry, 1960-1990, (Chicago: The University of Chicago Press, 1990), pp. 178-182.

20. Piero Gleijeses, "Moscow's Proxy? Cuba and Africa 1975-1988," Journal of Cold War Studies, Vol. 8, No. 2 (2006): pp. 98-146.

21. Vladimir G. Shubin, The Hot "Cold War": The USSR in Southern Africa, (London: Pluto Press, 2008).

22. Richard Pankhurst, "The Russians in Ethiopia: Aspirations of Progress," in Matusevich (ed.), Russia in Africa: Three Centuries of Encounters.

23. Festus Eribo, In Search of Greatness: Russia's Communications with Africa and the World, (Westport: Ablex Publications, 2001).

24. See, Charles Quist-Adade, In the Shadows of the Kremlin and the White House: Africa's Media Image from Communism to Post-Communism, (Lanham: University Press of America, 2001); Maxim Matusevich, "Black in the U.S.S.R.," Transition, No. 100 (2008), pp. 56-75.

25. See, Rosie Collyer, "Pushkin's Grandfather and Other Africans," New African, No. 488 (October 2009), pp. 94-96.
26. Ariel Cohen, "Russia's New Scramble for Africa," The Wall Street Journal Europe, (July 2, 2009), retrieved from https://www.wsj.com/articles/ SB124639219666775441.

27. See, Edward Lucas, The New Cold War: Putin's Russia and the Threat to the West, (New York: St. Martin's Press, 2009).

28. Beaumont, "Russia's Scramble for Influence in Africa Catches Western Officials Off-Guard."

29. See, Jack Losh and Owen Matthews, "Battle for Africa: Russia Pushes into 'Free Country for the Taking' in Attempt to Rival the West," Newsweek Magazine, (August 9, 2018), retrieved November 10, 2018, from https://www.newsweek.com/ 2018/08/17/russia-putin-africa-kremlin-centralrepublic-devastated-power-dynamic-1061066. html; "Profile: Central African Republic's Michel Djotodia," BBC News, (January 11, 2014), retrieved November 10, 2018, from https://www.bbc.com/ news/world-africa-21938297.

30. Alexander Winning, "Russia's Putin Raises Nuclear Deal at Ramaphosa Meeting during BRICS," Reuters, (July 30, 2018), retrieved November 10, 2018, from https://www.reuters.com/article/ us-safrica-nuclear/russias-putin-raises-nuclear-deal-at-ramaphosa-meeting-during-bricsidUSKBN1KG0S5.

31. See, Sergey Mazov, A Distant Front in the Cold War: The USSR in West Africa and the Congo, (Stanford: Stanford University Press, 2010).

32. Patricia Huon and Simon Ostrovsky, "Russia, the New Power in Central Africa," Coda Story, (December 19, 2018), retrieved December 21, 2018, from https://codastory.com/disinformation-crisis/foreign-proxies/russia-new-powercentral-africa.

33. See, Losh and Matthews, "Battle for Africa: Russia Pushes into 'Free Country for the Taking' in Attempt to Rival the West."

34. Vladimir Putin, "Annual Address to the Federal Assembly of the Russian Federation," President of Russia Events, (April 25, 2005), retrieved October 23, 2018, from http://en.kremlin.ru/events/president/transcripts/22931. 


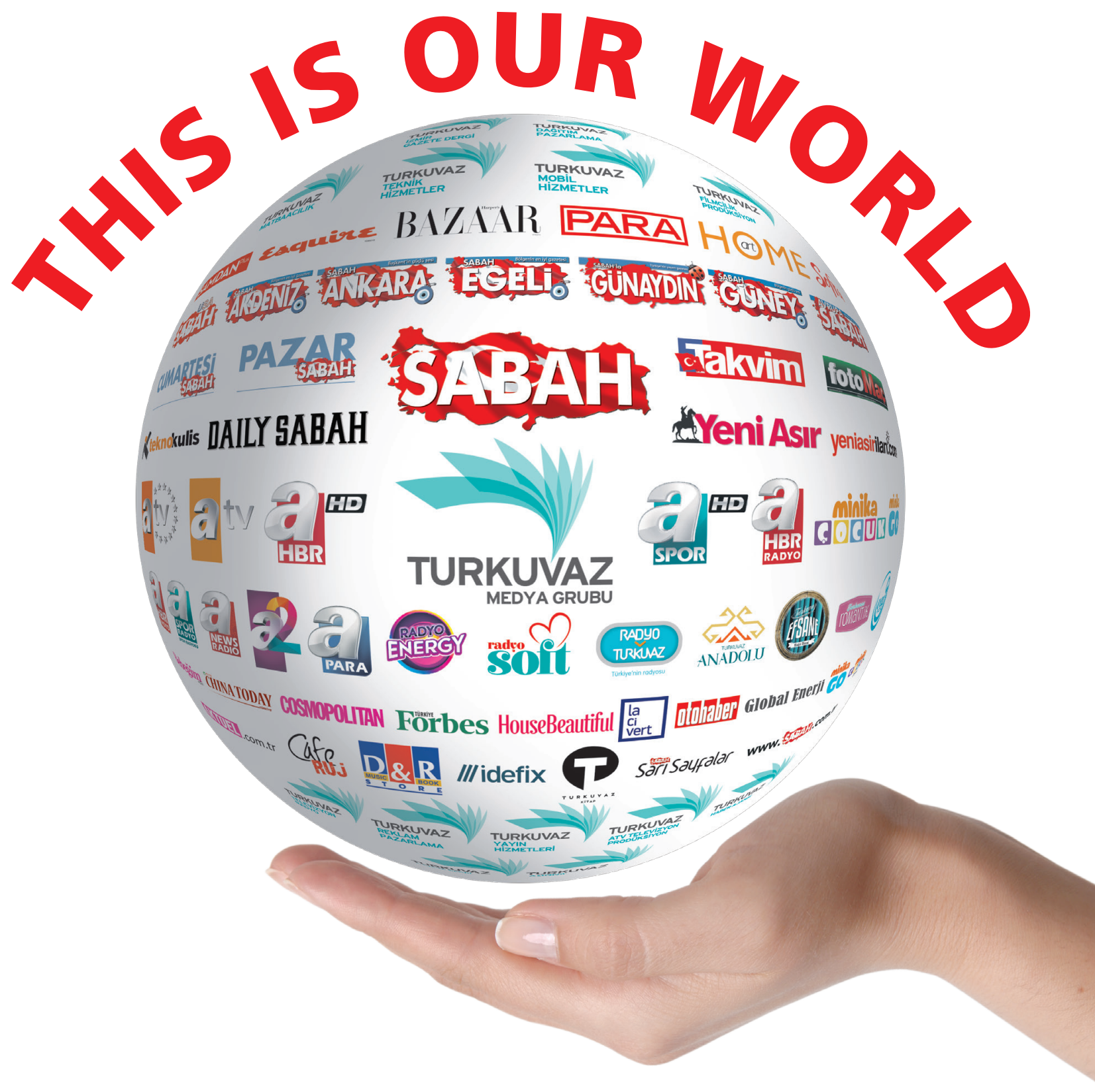

Turkuvaz Media Group is the leading group of companies which deals with broadcasting, publishing and distribution activities in Turkey. Most reputable national and international magazines, best selling local and national newspapers and prestigious tv channels create the most powerful synergy in Turkish media.

The opportunity to utilize this power for your advertisements is in your hands. Why not use it? 